\title{
A new approach for designing a hypolimnetic oxygenation system to improve the water quality in tropical reservoirs
}

\author{
Mashallah Moridi $^{(\mathbb{D}}$, Neamatollah Jaafarzadeh Haghighi Fard ${ }^{1}{ }^{\circledR}$, Abdolrahim Pazira $^{2^{+}}{ }^{(}$Fazel Amiri $^{2^{\circledR}}$, Esmaeil \\ Kouhgardi $^{\mathbb{D}}$
}

${ }^{1}$ Toxicology Research Center, Ahvaz Jundishapur University of Medical Sciences, Ahvaz, Iran

${ }^{2}$ Department of Environmental Engineering, Bushehr Branch, Islamic Azad University, Bushehr, Iran

\begin{abstract}
Background: One of the most important problems of dams is thermal layering which directly affects the water quality. This study was performed to propose a solution to increase the water quality of the Esteghlal Dam reservoir in Minab, Hormozgan.

Methods: The water quality of Esteghlal Dam was evaluated from 2016 to 2018. During this period, 18 samples were collected from three different points of the dam. The parameters of water temperature, electrical conductivity, total dissolved solids, total suspended solids, dissolved oxygen (DO), pH, nitrate, phosphate, turbidity, biochemical oxygen demand, chemical oxygen demand, total hardness, anions and cations, total phosphorus, physicochemical, and microbial parameters were measured according to the method recommended in the standard method book. The obtained data were used as the input for the model of reservoir water quality (CE-QUAL-W2) to simulate reservoir water quality and predict the thermocline cycle. Finally, by plotting hypolimnion oxygen content against time and finding the slope of regression line using the data, the hypolimnetic oxygen demand (HOD) was obtained.

Results: The findings showed that the anaerobic condition occurred in the hypolimnion layer during summer. Furthermore, it was revealed that the HOD of Esteghlal Dam is about $6 \mathrm{~g}$ of oxygen per square meter per day in the current situation.

Conclusion: Considering the dam's conditions and its anaerobic problems, a hypolimnetic oxygenation system is proposed as a structural solution for this reservoir. Then, conductivity-temperature-depth (CTD) profiles and monitoring data were used for the oxygen supply model of plume. The reservoir was predicted after calculating the amount of oxygen required using the equations governing linear oxygen supply systems and the plume model.

Keywords: Anaerobiosis, Oxygen consumption, Water quality, Phosphorus, Ammonia

Citation: Moridi M, Jaafarzadeh Haghighi Fard N, Pazira A, Amiri F, Kouhgardi E. A new approach for designing a hypolimnetic oxygenation system to improve the water quality in tropical reservoirs. Environmental Health Engineering and Management Journal 2020; 7(4): 277-285. doi: 10.34172/ EHEM.2020.33
\end{abstract}

\section{Article History:}

Received: 6 September 2020

Accepted: 24 October 2020

ePublished: 19 December 2020

\section{Introduction}

Considering the fact that Iran is located in an arid area with low precipitation, the construction of dams for water storage is essential. Among the primary goals of water, reservoir is the storage of surface water for drinking consumption. Stored water in dam reservoirs is contaminated due to point and nonpoint sources in the catchment area and the river. Besides, water contamination may be exacerbated by storage in reservoirs. Hence, it can put the physical, chemical, and biological conditions of stored water in the reservoir at risk. The central issues related to the contamination of water with organic matter that enters the reservoir reduce dissolved oxygen (DO) in the middle and lower layers and lead to the dehydration of stored water in hot seasons.
The oxygen consumption occurs in lakes and reservoirs due to the oxidation of reduced chemical species, the growth of algae, aquatic respiration, and aerobic decomposition of organic matters (1). During the time, the reservoirs undergo seasonal stratification, creating a warmer and less-dense epilimnion layer on the top, a transitionary thermocline or metalimnion layer in the middle, and a colder and denser hypolimnion layer at the bottom (1). The density gradient limits oxygen transfer from the top layer to the lower (hypolimnion) layer (2). Reducing DO in the hypolimnion layer is exacerbated as algae grow in the photic zone, complete their life cycle, and degraded as they settle through the water column. This settling organic detritus undergoes the aerobic decomposition in the presence of DO, contributing to water column 
oxygen demand (WOD). Incompletely-oxidized detritus settles through the hypolimnion and accumulates at the bottom, becomes incorporated into the sediment, which contributed to the sediment oxygen demand (SOD). The sum of WOD and SOD in the hypolimnion is an overall hypolimnetic oxygen demand (HOD) (3). If the HOD exceeds the available amount of DO in the hypolimnion, the HOD can cause anaerobic conditions with complete oxygen depletion in the hypolimnion (4).

Recently, Esteghlal reservoir has been exposed to the eutrophication due to obtaining various pollutants, especially livestock waste, urban and industrial wastewater, and runoff as well as the agricultural drainage. The main problems such as the unpleasant smell and taste of drinking water in Bandar Abbas, which is taken from Minab Dam should be paid much attention to improve the tank's water quality. One of the proposed solutions for this reservoir is a structural solution with non-structural alterations such as the laying of pipes for injection of oxygen to increase the oxygen level in the water, and as a result, improve its quality. Among the structural solutions, the hypolimnetic oxygenation system is considered as an effective solution. Hypolymphatic oxygenation is a technique which can be used by bottom water oxygenation with an engineering system of pure oxygen, instead of air, in conditions that maintain thermal classification of the lake (5), introduces oxygen by preventing anaerobicization of the bottom layer of the dam reservoir to improve the water quality conditions through injecting oxygen, and thus, to reduce the load of nutrients from surface sediments (6). Oxygen deficiency can also lead to hypolimnetic accumulation in reduced compounds such as ammonia and sulfides which are toxic to biotoxins (5), and can reduce metals such as iron and manganese which complicate drinking water purification (7).

The aim of this study was to propose and present a suitable solution to improve the water quality of the reservoir of Esteghlal Dam in Minab with a linear bubble column diffuser for the reservoir. The main components of this system include an oxygen generator, pump, porous pipe, plume diffuser, and a linear bubble on the pipe. Minab Dam is one of the water supply sources of Bandar Abbas, and unfavorable smell and taste can be easily recognized in some seasons of the year. There are many public complaints in this regard. Besides, several successful and unsuccessful methods of aeration and oxygenation of the reservoir were used to increase hypolimnetic oxygen concentration around the world (8). However, there is no case study on the Iranian reservoirs' hypolimnetic oxygenation system.

\section{Materials and Methods Methods}

The water quality of Esteghlal Dam was evaluated from 2016 to 2018. During this period, to determine the quality of incoming water, one-year sampling was performed at monthly intervals; hence, 18 samples were collected from three different points of the dam including $\mathrm{L} 1, \mathrm{~L}$ 2 , and L 3 (Figure 1). Some parameters such as $\mathrm{pH}$, water temperature, EC, DO, depth, total dissolved solids, and total suspended solids were used to improve water quality profiles in monitoring stations using multi-parameter CTD probe. Other parameters such as nitrate, phosphate, biochemical oxygen demand, chemical oxygen demand, total hardness, anions and cations, and total phosphorus were used in the calibration of measured model according to the methods recommended in the standard method book. The turbidity was measured by a disk diameter. The data were used as the input for the reservoir water quality model (CE-QUAL-W2) to simulate the reservoir water quality and predict the thermocline cycle. After simulation of the reservoir water quality, the water quality classification conditions were determined. The depth and volume of different layers were determined and calculated. To determine the amount of oxygen required in the hot seasons, in which the concentration of DO in the lower layer decreases, the volume of this mass was determined. For the concentration of DO in water, the required oxygen mass was calculated. The calculated volume or oxygen mass is the amount of oxygen which should be diffused by diffusers into the anaerobic layer to increase the oxygen concentration.

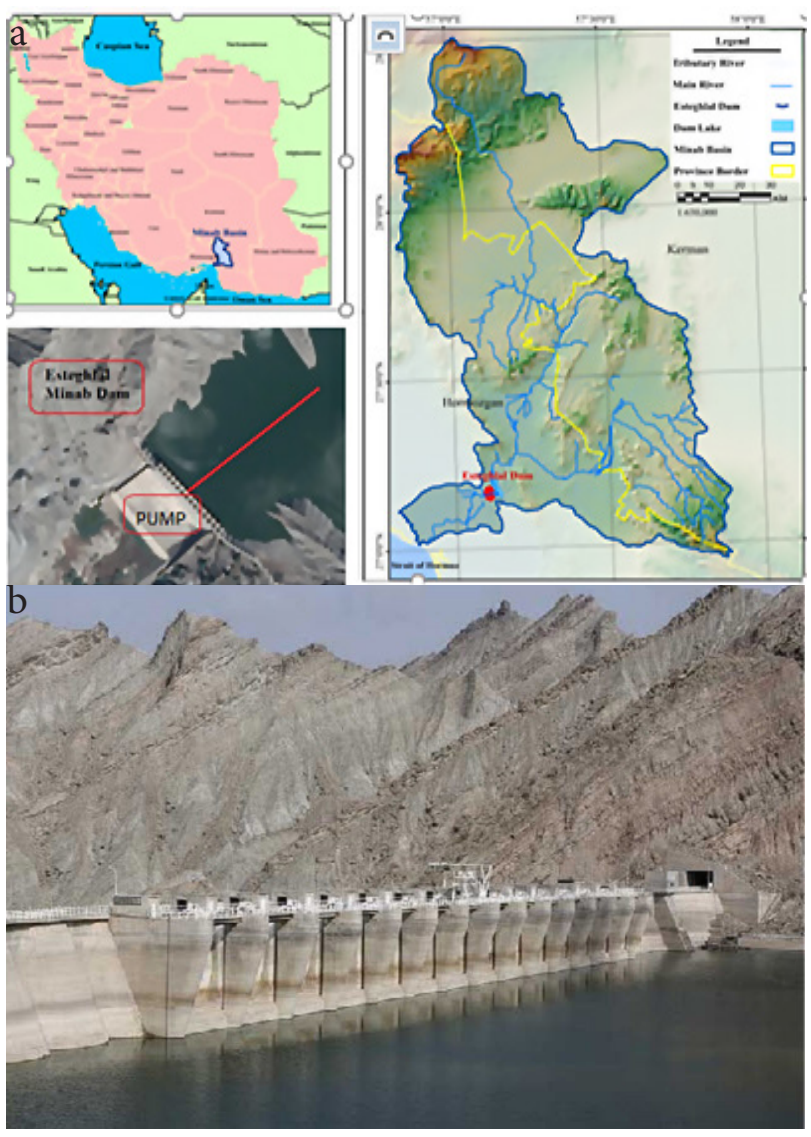

Figure 1. (a) Esteghlal Dam basin, its reservoir and monitoring stations; (b) view of Esteghlal reservoir 
In fact, to calculate the HOD, the vertical temperature profile up to the boundary between metalimnion and hypolimnion, and corresponding hypolimnetic volume were determined. By designing the hypolimnion oxygen rate over time and finding the slope of regression line using the data, the HOD was obtained.

\section{Study area}

Esteghlal Dam is located in Hormozgan province in the south of Iran at geographic location of $57^{\circ} 6^{\prime} 42^{\prime \prime} \mathrm{E}$ and $27^{\circ} 9^{\prime} 53^{\prime \prime} \mathrm{N}$ on Minab river (Figure 1). Esteghlal Dam is a concrete dam with a height of $60 \mathrm{~m}$ from the foundation, and a normal reservoir volume of 350 million cubic meters. In addition to agricultural water supply, the dam supplies a significant portion of Hormozgan municipal drinking water.

\section{Data collection}

The OCEAN SEVEN 316Plus CTD multi-parameter probe (20 Hz sampling rate) (Figure 2) was used to collect and record the temperature and DO profiles on a longitudinal transect in three locations in Esteghlal reservoir (L1, L2, and L3 in Figure 1). A combo water tester (8603 Handheld IP67) was used along with CTD to obtain and control the lower vertical resolution profiles on $0.5 \mathrm{~m}$. Data were collected monthly from April 2016 to 2017. In this study, DO and temperature conditions in the reservoir were measured before, during, and after the stratification.

\section{Data analysis}

After sampling and simulation of reservoir water quality, the status of water quality stratification was determined. The depth and volume of different layers were determined and calculated. Considering that the concentration of DO in the lower layer decreases in the hot seasons, the amount of HOD should be calculated. For this purpose, the vertical temperature should first be determined to determine the boundary between metalimnion and hypolimnion, and the corresponding hypolimnetic volume. After determining the level of oxygen in the upper layer, the amount of oxygen required was determined in terms of its volume. Due to the concentration of DO in water, the required mass of oxygen was calculated. The anaerobic layer was blown to increase oxygen concentration. Figure 3 shows the temperature and DO profile at the deepest point of the independence reservoir (L1). Other parts of the reservoir (L2 and L3) had a similar trend.

Temperature profile (Figure 3a) and CE-QUAL-W2 simulation outputs (Figure $4 \mathrm{a}$ ) show that the thermal stratification of the Esteghlal reservoir begins in late spring (May). In summer, by increasing air temperature, thermal stratification intensifies and lasts to the end of summer (September). According to Figure 3a, the most changes in temperature profile occur in July. Subsequently, by the beginning of autumn, air temperature decreases and autumn winds begin to blow; thus, the reservoir becomes mixed. This situation continues until next spring.

Dissolved oxygen profile (Figure $3 \mathrm{~b}$ ) and CE-QUAL-W2 simulation output (Figure $4 \mathrm{~b}$ ) show that by simultaneous thermal stratification in the summer, the amount of DO in hypolimnetic layer is reduced and the hypoxic condition occurs. The worst-case occurs in August, July, and partly in September, in which the amount of DO in hypolimnetic layer reaches near to zero. During these months, fish mortality is observed.

\section{Determination of hypolimnetic oxygen demand}

To determine the HOD, data of vertical CTD profile were used. This process is as follows (1):
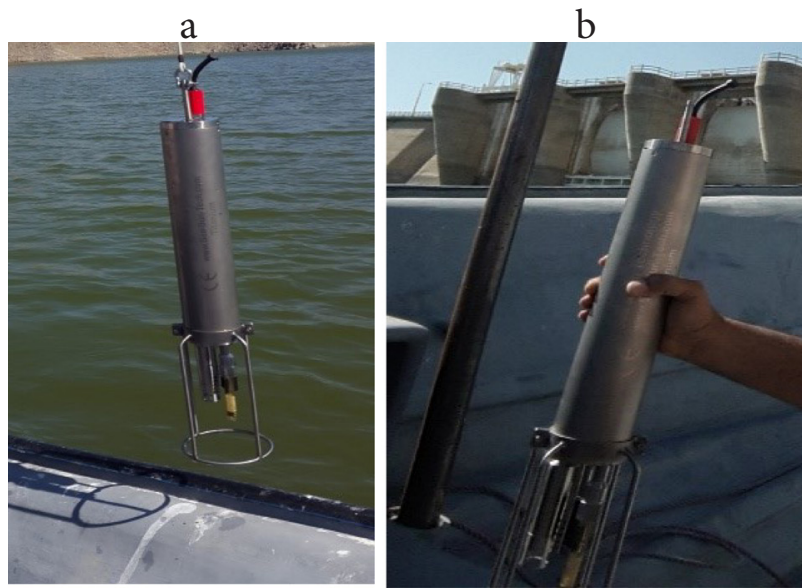

Figure 2. (a) Using CTD in Esteghlal reservoir; (b) Reading CTD data on the sampling device.

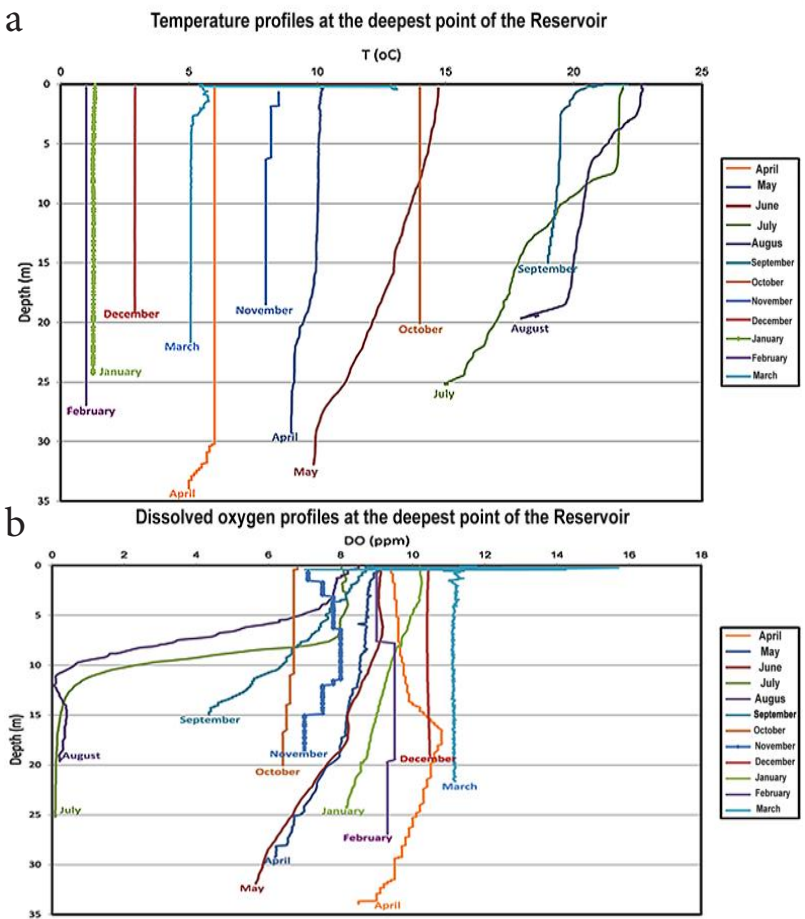

Figure 3. (a) Temperature profile; (b) dissolved oxygen profile at the deepest point of Esteghlal reservoir using CTD. 


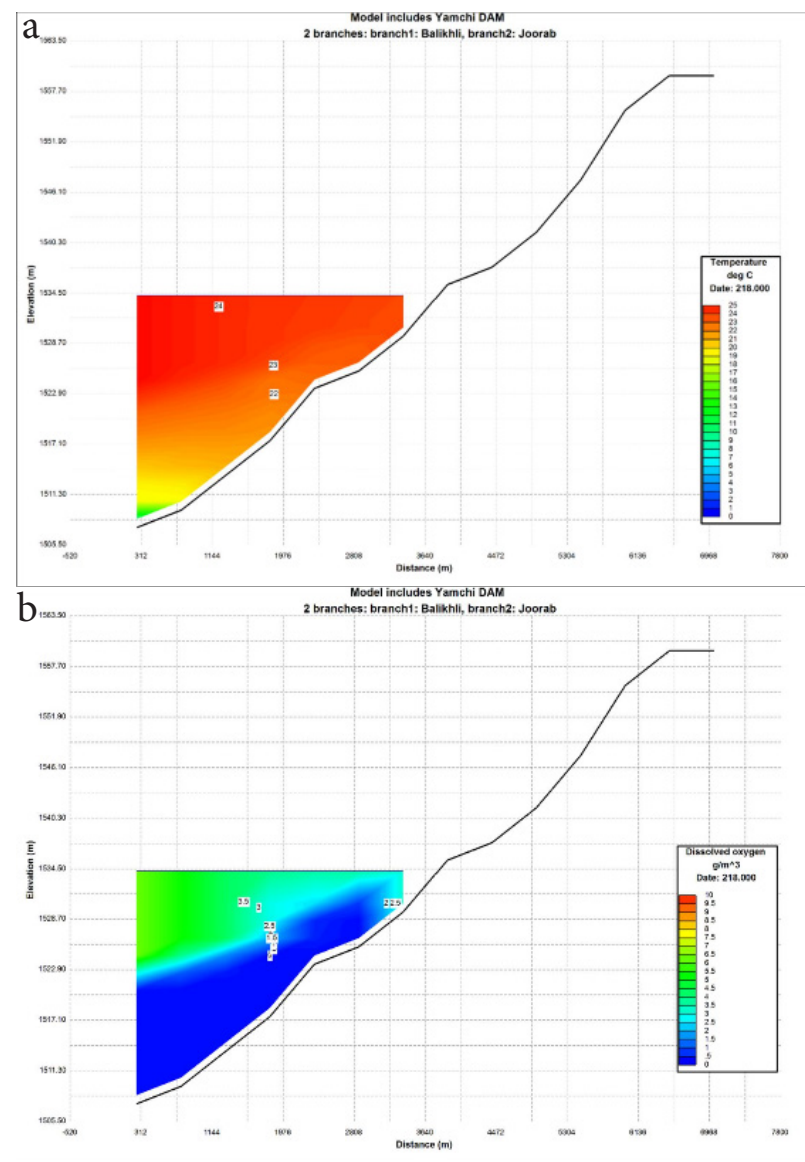

Figure 4. (a) Temperature longitudinal profile; (b) dissolved oxygen longitudinal profile in summer according to the CEQUAL-W2 model output.

First, temperature profiles were analyzed to determine the thermocline period, thermocline location, the boundary between metalimnion and hypolimnion, and corresponding hypolimnetic volume.

Esteghlal reservoir was divided into three sections (longitudinal sampling sections) and $0.1-\mathrm{m}$ layers (sampling depth and CTD profile). It created a section (x)-layer ( $\mathrm{z}$ ) grid, which divided the reservoir into cells.

Thevolume-weighted totalmassofoxygeninhypolimnion was calculated by multiplying the oxygen concentration (DOx,z) by the corresponding cell volume (Volx,z) and summing the results for all cells in the thermocline period:

$$
\operatorname{Mass}(\text { Oxygen Content })=\sum_{x=1}^{s} \sum_{z=1}^{n} D O_{x, z} \times V o l_{x, z}
$$

Where, Mass (oxygen content) is the total volume - weighted oxygen mass $\left(\mathrm{kg}-\mathrm{O}_{2}\right), D O x, z$ is the oxygen concentration in section $(\mathrm{x})$ and layer $(\mathrm{z}), \operatorname{Vol} x, z$ is cell volume corresponding to section (x) and layer $(\mathrm{z}), s$ is the number of sections, and $n$ is the number of layers.

The HOD mass as a function of oxygen mass was calculated by plotting the oxygen content in the hypolimnion against time and finding the slope of regression line using the data (9).

\section{Linear bubble plume model}

Burris et al originally developed bubble plume model equations (10). However, the equations were modified by Matthews et al (11) and refined by Singleton and Little (12).

The linear bubble plume model is comprised of horizontally integrated equations based on the mass, momentum, and heat conservation. Eight flux equations are simultaneously solved to predict the water flow rate, plume temperature, oxygen and nitrogen transfer and concentration, salinity, and plume rise height, given diffuser geometry and depth, applied gas flow rate, and the initial bubble size (Tables 1 and 2) (13).

Where, $b$ is the plume radius (circular bubble plume) $(\mathrm{m}), d$ is the bubble diameter $(\mathrm{mm}), C$ is DO concentration $\left(\mathrm{mol} / \mathrm{m}^{3}\right), E$ is the entrainment factor $\left(\mathrm{m}^{2} / \mathrm{s}\right), F D$ is the dissolved species flux ( $\mathrm{mol} / \mathrm{s}), F G$ is the gaseous species flux $(\mathrm{mol} / \mathrm{s}), F S$ is the salinity flux $(\mathrm{kg} / \mathrm{s}), F T$ is the temperature flux $\left(\mathrm{C} \mathrm{m}^{3} / \mathrm{s}\right), \mathrm{Fr}$ is the Froude number, $g$ is the gravitational acceleration $\left(\mathrm{m} / \mathrm{s}^{2}\right), H$ is the Henry's constant $\left(\mathrm{mol} / \mathrm{m}^{3} / \mathrm{bar}\right), K L$ is the mass transfer coefficient $(\mathrm{m} / \mathrm{s}), L$ is plume length $(\mathrm{m}), M$ is water momentum, $\left(\mathrm{m}^{4} / \mathrm{s}^{2}\right), N$ is the number of bubbles $(1 / \mathrm{s}), P$ is pressure (bar), $Q$ is plume flow rate $\left(\mathrm{m}^{3} / \mathrm{s}\right), q$ is the actual gas flow rate per unit diffuser length $\left(\mathrm{m}^{2} / \mathrm{h}\right), R i$ is the Richardson number, $R$ is the bubble radius $(\mathrm{m}), S$ is salinity $(\mathrm{g} / \mathrm{kg})$, $T$ is temperature $(\mathrm{C}), \mathrm{n}$ is velocity $(\mathrm{m} / \mathrm{s}), W$ is the plume width $(\mathrm{m}), y$ is gas concentration $\left(\mathrm{mol} / \mathrm{m}^{3}\right), Z$ is bubble column depth (m), $a$ is the entrainment coefficient, $l$ is the spreading coefficient, $r$ is the ratio of material volume to its mass $\left(\mathrm{kg} / \mathrm{m}^{3}\right), G$ is the Gaussian profile, $O$ is oxygen, $N$ is nitrogen, $T$ is top-hat profile, $a$ is ambient water, $b$ is bubble, $i$ is gas species, oxygen or nitrogen, $o$ is the initial oxygen concentration, $p$ is plume water and gas mixture, and $W$ is plume water.

Based on the monitoring data, Esteghlal reservoir has thermal stratification in May, August, and July. During these months, the hypolimnion was located approximately 10,7 , and $4 \mathrm{~m}$ below the water surface. As a result, the oxygen content in the hypolimnion was calculated during these months using Eq. (1). Finally, by plotting oxygen content in the hypolimnion against time and finding the slope of regression line based on the data, the HOD was obtained.

Figure 5 shows the hypolimnion oxygen content diagram and regression line of Esteghlal reservoir during the thermocline cycle.

\section{Results}

The results showed that temporal and spatial changes in temperature, as well as the modeled water quality parameters, are relatively well consistent with the observational data. The modeling results showed that the reservoir of Minab Dam has stratification in the summer, which starts from the end of March and lasts for 10 months to December. During this period, the hypolimnion is 
Table 1. Key variables of the linear bubble plume model (10)

\begin{tabular}{|c|c|c|}
\hline Variable & Formula & Unit \\
\hline Entrainment factor & $Q=L W v$ & $\mathrm{~m}^{2} / \mathrm{s}$ \\
\hline Plume water volume flux & $Q=L W v$ & $\mathrm{~m}^{3} / \mathrm{s}$ \\
\hline Momentum flux & $M=L W v^{2}$ & $\mathrm{~m}^{4} / \mathrm{s}^{2}$ \\
\hline Temperature flux & $F_{T}=Q T_{p}$ & ${ }^{\circ} \mathrm{C} \mathrm{m} / \mathrm{s}$ \\
\hline Dissolved solids flux & $F_{s}=Q S_{\rho \omega}$ & $\mathrm{kg} / \mathrm{s}$ \\
\hline Dissolved $\mathrm{O}_{2}$ and $\mathrm{N}_{2}$ fluxes & $F_{D_{i}}=Q C_{i}$ & $\mathrm{~mol} / \mathrm{s}$ \\
\hline Gaseous $\mathrm{O}_{2}$ and $\mathrm{N}_{2}$ fluxes & $F_{G_{i}}=\lambda W[L-W(1-\lambda)]\left(v+v_{b}\right) y_{i}$ & $\mathrm{~mol} / \mathrm{s}$ \\
\hline
\end{tabular}

Table 2. Non-linear differential flux equations of the linear bubble plume model (10)

\begin{tabular}{ll}
\hline Flux & Equation \\
\hline Water volume & $d Q / d z=E$ \\
\hline Momentum & $d M / d z=\left[\left(\rho_{a}-\rho_{w}\right) / \rho_{p}\right] g \lambda W+\left[\left(\rho_{w}-\rho_{p}\right) / \rho_{p}\right] g \lambda W[L-W(1-\lambda)]$ \\
\hline Temperature & $d F_{T} / d z=E T_{a}$ \\
\hline Salinity & $d F_{S} / d z=E \rho_{a} S_{a}$ \\
\hline Dissolved gas & $d F_{G_{i}} / d z=-\left[4 \pi r^{2} N /\left(v+v_{b}\right)\right] K_{L}\left(H_{i} P_{i}-C_{i}\right)$ \\
Gas & $d F_{G_{i}} / d z=-\left[4 \pi r^{2} N /\left(v+v_{b}\right)\right] K_{L}\left(H_{i} P_{i}-C_{i}\right)$ \\
\hline
\end{tabular}

approximately 10, 7, and $4 \mathrm{~m}$ below the water level. Field studies during the reservoir stratification period showed that in these months, when thermal stratification occurs in the reservoir of Minab Dam, the smell and color of drinking water in Bandar Abbas change and cause some problems for consumers. The resulting classification causes anaerobic conditions in the depth of the reservoir and prevents the vertical transfer of DO to the depth of the reservoir. Therefore, to prevent these conditions, the oxygen content required by the hypolimnion during the above-mentioned months was calculated using Eq. (1). Also, it was found that the reservoir experienced complete mixing for two months during the year, which was in the category of warm monomictic lakes. The oxygen content required by the $\mathrm{HOD}$ was estimated to be $2210 \mathrm{~kg} \mathrm{O}_{2}$ per day. Due to uncertainty as well as the involvement of other parameters in the calculation including incompletely oxidized particles, SOD, the amount of oxygen in metals, organic matters in the tank, growth of algae, estimated DO, etc, a safety factor between 2 and 3 is recommended (14). In this study, after consultation with experts, the safety factor was considered to be 2.5. As a result, the HOD was estimated to be $5525 \mathrm{~kg} \mathrm{O}_{2}$ per day, or 3.4 L.O 2 per minute. As the tank surface area during the thermocline period was equal to $0.93 \mathrm{~km}^{2}$, the $\mathrm{HOD}$ was about $6 \mathrm{~g} . \mathrm{O}_{2} / \mathrm{m}^{2}$ per day.

\section{Discussion}

Evaluation of the simulation model of the Esteghlal dam reservoir showed that the reservoir water experiences stratification for about 10 months and complete mixing twice a year. Therefore, it is classified as dimictic lakes. In addition to temperature, DO was also simulated in this study. The presence of water-soluble oxygen is a positive sign, and its absence is a negative sign in the direction of pollution (15). Highly soluble oxygenated waters are considered as stable and healthy ecosystems and a priority for consumption almost everywhere (16). Most DO enters the water from the atmosphere, and the turbulence of water is considerable. It increases the amount of DO. On

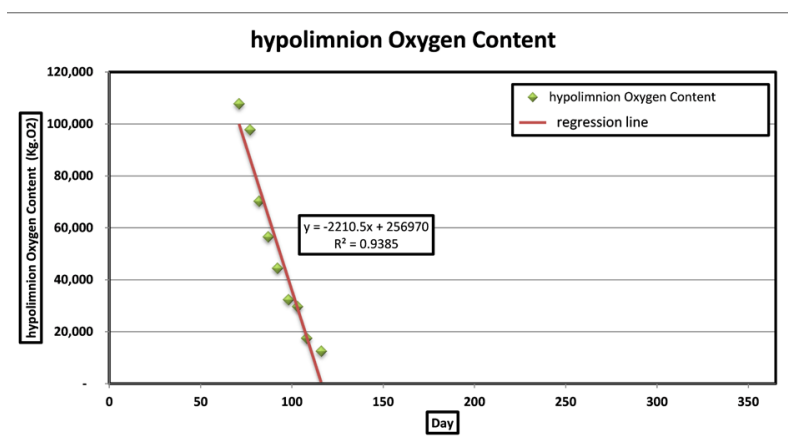

Figure 5. Diagram of hypolimnion oxygen content in Esteghlal reservoir. 
the other hand, aquatic plants and algae enter the water in solution during photosynthesis per day in large quantities. Water temperature and flow rate are the most effective factors in determining the amount of DO. Gases, including oxygen are easily soluble in cold water. Therefore, water sources with lower temperatures generally have higher DO concentrations (17). Another factor, which affected the dam's layering and was mentioned in the guide of water quality studies on large dams reservoirs in Iran (No. 550), is the impact of climate and latitude of dam. The climate and latitude of dam site clearly affect the reservoir tendency to be stratified. In general, there are 5 different modes for the above-mentioned subject which were presented for areas with 5 layers based on the latitude, among which the following classification prediction can be used for areas with a latitude less than $1000 \mathrm{~m}$.

Latitude 0 to 25: The formation of long-term or shortterm thermal stratification depends on the height of dam site. At lower altitudes, the reservoir tends to form longterm stratification, and at higher altitudes, the reservoir tends to form short-term stratification. In the latter case, due to poor stratification, mixing several times a year is possible.

Latitude 25 to 40: Under these conditions, at a temperature higher than $4^{\circ} \mathrm{C}$, thermal rotation in the tank easily occurs in winter, and we will have thermal stratification in summer.

Latitude 40 to 60: In this latitude, the dam reservoir has thermal rotation twice a year and completely free in autumn and spring, and as a result, it is layered in winter and summer.

Latitude 60 to 80: There is no stratification in winter, and thermal rotation only occurs once a year in the summer. Therefore, Minab Dam is located at the latitude of 40 to 60 , which mixes twice a year. This mixing leads to the transference of high oxygen concentrations in the upper layers to the lower layers in the tank. In Minab Dam, due to the 10-month period of layering for the lower layer, the level of oxygen is very low, and anaerobic conditions prevail. To prevent this condition, it was suggested to use a pipe to supply oxygen to the lower layer. There is no similar study in Iran.

The results obtained from 8 sites in the USA indicate that diffuser technology effectively increased hypolimnetic DO. The maintained diffuser systems increased DO in the hypolimnion during successive years of the operation in every site $(18,19)$. The results of research on Lake Bard, California, with adding oxygen showed that oxygen addition averaged $380 \mathrm{~kg} / \mathrm{d}$ and increased bottom water DO from 1-2 to 5-6 mg/L with a concurrent drop in water column phosphate and iron, and a delay in the release of ammonia from sediment. By its low oxidation kinetics, manganese remained in bottom waters during the oxygenation test, indicating that the oxygenation system needs to be turned on earlier in the season to better control manganese accumulation in the bottom waters (20). The situation of Minab Dam needs to create a way to inject oxygen into the lake and control stratification, which is completely given below.

A linear bubble plume diffuser is proposed for the Esteghlal reservoir. The main components of this system include an oxygen generator with a capacity about 3.4 L. $\mathrm{O}_{2} / \mathrm{min}$, a pump with an applied gas flow rate of 100 standard cubic feet per minute (SCFM), a porous pipe with a length of $1200 \mathrm{~m}$, and a linear bubble plume diffuser on the pipe with the bubble size (diameter) of $1.16 \mathrm{~mm}$. These numbers are based on the results of oxygenation plume model.

A schematic of the diffuser system is shown in Figure 6a. This system is consisted of a porous pipe which is expanded over the reservoir bed (Figures $6 b$ and 7 ). This pipe is filled with oxygen, and by going through the holes and entering the reservoir, a mixture of water and oxygen is formed. Due to the density difference with the surrounding water, this mixture began to rise upwards like a plume (Figure 8).

The bubble-water mixture is essentially the "plume". The plume entrains cold water near the bottom. As the plume rises, it loses its momentum due to the density gradient in the water column and energy to lift the colder/ denser water. At this point, the water in the plume is colder than the surrounding water, but is warming when it is entrained from the bottom. Then, the bubble columns were cascaded in the layer of hypolimnion, according to the density of the layer.

Also, the upward movement of bubbles causes mixing and circulation in water, accelerating the transfer of oxygen to water. This mixture continues to rise, until it loses its energy and will no longer be able to rise. At this elevation, it will plunge into ambient waters. Raising the level of this mixture is among the critical parameters in designing systems. The bubble injection site should be placed under the thermocline layer so that it does not distribute or inject oxygen into the thermocline layer. Mixing in the Esteghlal reservoir occurs twice a year, so the reservoir is dalmatic. By examining the temperature changes in different lakes in similar climatic conditions, it was found that the average daily temperature in different lakes is similar. Besides, Gantzer et al (21) examined the temperature changes in different lakes in similar climatic

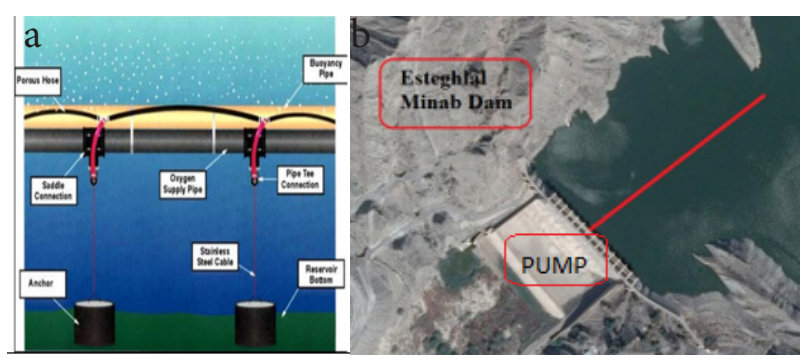

Figure 6. (a) Schematic of linear bubble plume diffuser (18); (b) piping in Esteghlal reservoir . 


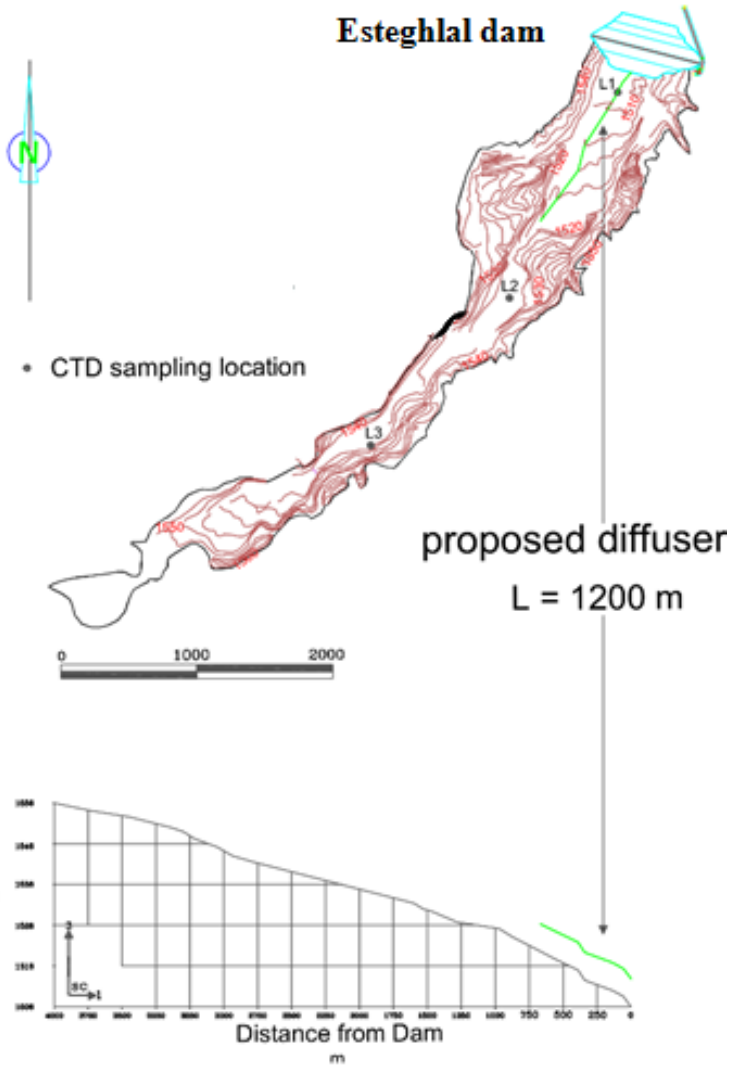

Figure 7. Bathymetric map of Esteghlal reservoir, showing the location of linear bubble plume diffuser.

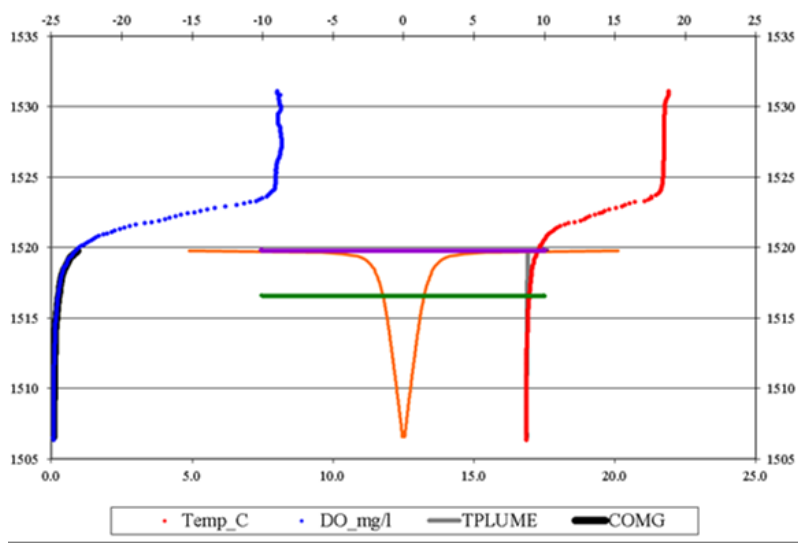

Figure 8. Predicting the plume rise of Esteghlal reservoir. Green line: the elevation of equal density, violet line: the depth of the maximum plume rise, and orange line: the predicted width of the plume.

conditions and found that the average daily temperature in different lakes is similar, so that in spring, there is a small difference among them, while in summer, smaller lakes absorb more heat $(22,23)$. The presence of watersoluble oxygen is a positive sign, and its absence is a negative sign in the direction of pollution. Highly soluble oxygenated water is considered as a stable and healthy ecosystem, which is given the priority for consumption almost everywhere. Most DO enters the water from the atmosphere and water turbulence $(24,25)$, therefore, the level of DO increases significantly. On the other hand, aquatic plants and sometimes algae are also present during photosynthesis.

A linear bubble column diffuser was proposed for the independence tank. The main components of this system include an oxygen generator with a capacity about 3.4 L. $\mathrm{O}_{2} / \mathrm{min}$, a pump with applied gas flow rate of 100 SCFM, a porous pipe with a length of $1200 \mathrm{~m}$, and a linear bubble diffuser on the pipe with a bubble size (diameter) of 1.16 $\mathrm{mm}$. These numbers depend on the results of plume oxygenation model.

A schematic of the diffuser system is shown in Figure 6a. The system is consisted of a porous tube that is expanded on the tank bed (Figure $6 \mathrm{~b}$ and 7). This porous tube is filled with oxygen, passes through the holes, and enters the tank, forming a mixture of water and oxygen. Due to the difference in density with the surrounding water, the mixture began to rise like a column (Figure 8).

The mixture of water and bubbles is basically a "column". It combines a column of cold water near its end. As the column rises, it loses its motion due to the density gradient in the column and the energy to continue lifting colder and denser water. At this stage, the water in the column which is colder than the water around it, heats up when it is neutralized from the bottom. Then, the bubble columns were cascaded in the layer of hypolimnion, according to the density of the layer.

Also, the upward movements of bubbles cause mixing and circulation in water, accelerating the transfer of oxygen to water. This mixture continues to increase, until it loses its energy and is no longer able to increase. At this altitude, it will plunge into ambient water. Increasing the level of this mixture is one of the vital parameters in designing systems. It should be adjusted to be under the thermocline layer which prohibits the distribution or injection of oxygen in thermocline layer.

The cost of system is estimated to be US\$15000 for oxygen generator and pump, US\$110000 for piping and its joints. The total cost is estimated to be US\$125000. The cost of electricity (including $7 \mathrm{kWh}$ for oxygenation and pumping system, and 12 hour per day) is estimated to be US\$600 per month. As a result, the overall cost is about US\$125600. Compared to other systems, the main advantage of this system is its lower cost as well as the ease of installation and operation.

\section{Conclusion}

Due to the variations in air temperature, thermal stratification occurs overtime for the reservoirs. This process can cause the oxygen depletion in the bottom layer of water or hypolimnion and it has adverse effects on the water quality including smell, color, taste, and so on. The present study on Esteghlal Dam indicated that this reservoir due to the entrance of various pollutants, is 
subjected to an anaerobic condition in the hypolimnion during summer. In this study, a hypolimnetic oxygenation system was proposed, and its details were discussed. Besides, using a non-structural solution (oxygen injection or increasing DO level), can be an effective solution for improving the water quality in Esteghlal reservoir.

\section{Acknowledgements}

This article is a part of Ph.D. thesis of Mashallah Moridi, in Environmental Engineering at Bushehr Azad University. The author would like to gratitude his supervisors, advisors, and Hormozgan Regional Water Laboratory who helped him with the water quality examinations.

\section{Ethical issues}

The authors certify that this manuscript is the original work of the authors, all data collected during the study are presented in this manuscript, and no data from the study has been or will be published elsewhere separately.

\section{Competing interests}

The authors declare that they have no conflict of interests.

\section{Author's contributions}

All authors contributed equally to the data collection, analysis, and interpretation. They also critically reviewed, refined, and approved the manuscript.

\section{References}

1. Winton RS, Calamita E, Wehrli B. Reviews and syntheses: dams, water quality and tropical reservoir stratification. Biogeosciences Discussions 2019; 16(8): 1657-71. doi: 10.5194/bg-2018-510.

2. Winton RS, Calamita E, Wehrli B. Physical data for the 54 most voluminous low latitude reservoirs. ETH Zurich; 2018. doi: 10.3929/ethz-b-000310656.

3. Zarfl C, Lumsdon AE, Berlekamp J, Tydecks L, Tockner K. A global boom in hydropower dam construction. Aquat Sci 2015; 77(1): 161-70. doi: 10.1007/s00027-014-0377-0.

4. Zhang L, Li QH, Huang GJ, Ou T, Li Y, Wu D, et al. Seasonal stratification and eutrophication characteristics of a deep reservoir, Longtan Reservoir in subtropical area of China. Huan Jing Ke Xue 2015; 36(2): 438-47. [In Chinese].

5. Dai L, Dai h, Jiang D. Temporal and spatial variation of thermal structure in Three Gorges Reservoir: a simulation approach. J Food Agric Environ 2012; 10(2): 1174-8.

6. Degefu F, Mengistu S, Schagerl M. Influence of fish cage farming on water quality and plankton in fish ponds: a case study in the Rift Valley and North Shoa reservoirs, Ethiopia. Aquaculture 2011; 316(1-4): 129-35. doi: 10.1016/j. aquaculture.2011.03.010.

7. Zhong Y, Power G. Environmental impacts of hydroelectric projects on fish resources in China. Regul Rivers Res Manage 1996; 12(1): 81-98. doi: 10.1002/(sici)10991646(199601)12:1<81::aid-rrr378>3.0.co;2-9.

8. Deus R, Brito D, Mateus M, Kenov I, Fornaro A, Neves $\mathrm{R}$, et al. Impact evaluation of a pisciculture in the Tucuruí reservoir (Pará, Brazil) using a two-dimensional water quality model. J Hydrol 2013; 487: 1-12. doi: 10.1016/j. jhydrol.2013.01.022.

9. Gantzer PA, Preece EP, Nine B, Morris J. Decreased oxygenation demand following hypolimnetic oxygenation. Lake and Reservoir Management 2019; 35(3): 292-307. doi: 10.1080/10402381.2019.1648614.

10. Burris VL, McGinnis DF, Little JC. Predicting oxygen transfer and water flow rate in airlift aerators. Water Res 2002; 36(18): 4605-15. doi: 10.1016/s0043-1354(02)001768.

11. Matthews DA, Effler SW Assessment of long-term trends in the oxygen resources of a recovering urban lake, Onondaga Lake, New York. Lake Reserv Manag 2006; 22(1): 19-32. doi: 10.1080/07438140609353881.

12. Kuo JT, Lung WS, Yang CP, Liu WC, Yang MD, Tang TS. Eutrophication modeling of reservoirs in Taiwan. Environmental Modeling and Software 2006; 21(6): 829-44. doi:10.1016/j.envsoft.2005.03.006.

13. Moore BC. Downflow bubble contact aeration technology (Speece Cone) for sediment oxygenation. In: Proceedings of the Second International Conference on Remediation of Contaminated Sediments. Venice; 2003.

14. Beutel M, Hannoun I, Pasek J, Kavanagh KB. Evaluation of hypolimnetic oxygen demand in a large eutrophic raw water reservoir, San Vicente Reservoir, Calif. J Environ Eng 2007; 133(2): 130-8. doi: 10.1061/(asce)07339372(2007)133:2(130).

15. Singleton VL, Little JC. Designing hypolimnetic aeration and oxygenation systems--a review. Environ Sci Technol 2006; 40(24): 7512-20. doi: 10.1021/es060069s.

16. Ashley K. Hypolimnetic Aeration: Practical Design And Application. Water Research 1985; 19(6): 735-40. doi: 10.1016/0043-1354(85)90120-4.

17. Fast AW, Overholtz WJ, Tubb RA. Hypolimnetic oxygenation using liquid oxygen. Water Resour Res 1975; 11(2): 294-9. doi: 10.1029/WR011i002p00294.

18. Singleton VL, Little JC. Designing hypolimnetic aeration and oxygenation systems--a review. Environ Sci Technol. 2006;40(24):7512-7520. doi:10.1021/es060069s.

19. Higashino M, Stefan HG. Sedimentary microbial oxygen demand for laminar flow over a sediment bed of finite length. Water Res 2005; 39(14): 3153-66. doi: 10.1016/j. watres.2005.05.032.

20. Gantzer PA, Bryant LD, Little JC. Controlling soluble iron and manganese in a water-supply reservoir using hypolimnetic oxygenation. Water Res 2009; 43(5): 1285-94. doi: 10.1016/j.watres.2008.12.019.

21. Gantzer PA, Bryant LD, Little JC. Effect of hypolimnetic oxygenation on oxygen depletion rates in two water-supply reservoirs. Water Res 2009; 43(6): 1700-10. doi: 10.1016/j. watres.2008.12.053.

22. Gerling AB, Browne RG, Gantzer PA, Mobley MH, Little JC, Carey CC. First report of the successful operation of a side stream supersaturation hypolimnetic oxygenation system in a eutrophic, shallow reservoir. Water Res 2014; 67: 129-43. doi: 10.1016/j.watres.2014.09.002.

23. Mobley M, Gantzer P, Benskin P, Hannoun I, McMahon S, Austin D, et al. Hypolimnetic oxygenation of water supply reservoirs using bubble plume diffusers. Lake 
and Reservoir Management 2019; 35(3):247-65. doi: 10.1080/10402381.2019.1628134.

24. Betancourt C, Jorge F, Suarez R, Beutel MW, Gebremariam SY. Manganese sources and cycling in a tropical eutrophic water supply reservoir, Paso Bonito Reservoir, Cuba. Lake and Reservoir Management 2010; 26(3):217-26. doi:
10.1080/07438141.2010.519856.

25. Debroux JF, Beutel MW, Thompson CM, Mulligan S. Design and testing of a novel hypolimnetic oxygenation system to improve water quality in Lake Bard, California. Lake Reserv Manag 2012; 28(3): 245-54. doi: 10.1080/07438141.2012.716501. 